\title{
TEKNOLOGI PENGOLAHAN AIR SIAP MINUM UNTUK DAERAH PADAT PENDUDUK
}

\author{
Oleh : \\ Wahyu Widayat \\ Kelompok Teknologi Pengelolaan Air Bersih \& Limbah Cair, P3TL- BPPT
}

\begin{abstract}
One of common problem on dense settlement area in Indonesia is the need for clean water and especially at rural and isolated areas this problem have not been properly solved yet. The ground and river water which consume by the community do not meet the requirement for drinking water, even at several places the water is not suitable to drink. The standard requirement for drinking water have to comply with the physical, chemical and biological requirements and if one parameter do not comply with the requirement then the water is not proper to drink.

Most of residential area in Indonesia have poor water quality and have not got clean water services from local PAM, therefore in order to fulfill the need for drinking water, the community buy bottled drinking water which is very expensive.

To overcome the above problem, a pilot unit package of technology have been developed, to treat well water or clean water from PAM to be direct to drink water ( no need to boiled it ). The unit consists of water pump, sand filter, mangan zeolit filter, activated carbon filter, cartridge filter, ultra violet sterilisator and ozon generator
\end{abstract}

Kata Kunci : Air tanah, air PAM, pengolahan air, air siap minum

\section{PENDAHULUAN}

Air merupakan salah satu materi yang tidak dapat dipisahkan dalam kehidupan manusia dengan segala aktivitasnya, sehingga merupakan kebutuhan pokok bagi kehidupan manusia. Apabila kebutuhan akan air tersebut belum tercukupi dapat memberikan dampak yang besar terhadap kerawanan kesehatan maupun sosial.

Di Indonesia pelayanan air bersih dalam skala besar masih terpusat di daerah perkotaan, dan dikelola oleh Perusahan Daerah Air Minum (PDAM) kota yang bersangkutan. Pelayanan penyediaan air bersih secara nasional masih jauh dari mencukupi dan dapat dikatakan relatif kecil yakni 16,08 \% (1995). Untuk daerah yang belum mendapatkan pelayanan air bersih dari PAM umumnya mereka menggunakan air tanah (sumur), air sungai, air hujan, air sumber (mata air) dan lainnya.

Berdasarkan data ststistik 1995, prosentasi banyaknya rumah tangga dan sumber air minum yang digunakan di berbagai daerah di Indonesia sangat bervariasi tergantung dari kondisi geografisnya. Secara nasional yakni sebagai berikut : Yang menggunakan air leding $16,08 \%$, air tanah dengan memakai pompa $11,61 \%$, air sumur (perigi) 49,92\%, mata air (air sumber) $13,92 \%$, air sungai $4,91 \%$, air hujan $2,62 \%$ dan lainnya $0,80 \%$.
Pada umumnya daerah padat penduduk air tanahnya tidak layak untuk dikonsumsi, karena sudah tercemar oleh air limbah domestik, industri, rumah sakit dan lainnya. Di daerah padat penduduk ini, ada beberapa permasalahan mendasar yang sering timbul yakni kulaitas air tanah maupun air sungai yang digunakan masyarakat kurang memenuhi syarat sebagai air minum yang sehat bahkan di beberapa tempat bahkan tidak layak untuk diminum. Air dengan kualitas layak diminum mempunyai standar persyaratan tertentu yakni persyaratan fisis, kimiawi dan bakteriologis, dan syarat tersebut merupakan satu kesatuan, sehingga apabila ada satu saja parameter yang tidak memenuhi syarat maka air tesebut tidak layak untuk diminum. Pemakaian air minum yang tidak memenuhi standar kualitas tersebut dapat menimbulkan gangguan kesehatan, baik secara langsung dan cepat maupun tidak langsung dan secara perlahan.

Air tanah pada umumnya mengandung zat besi (Fe) dan Mangan (Mn) cukup besar. Adanya kandungan Fe dan Mn dalam air ditandai dengan adanya perubahan fisis, yaitu ditunjukkan dengan perubahan warna air menjadi kuning-coklat setelah terjadi oksidasi, yaitu beberapa saat kontak dengan udara. Disamping dapat mengganggu kesehatan juga menimbulkan bau yang kurang enak serta menyebabkan warna kuning pada dinding bak 
serta bercak-bercak kuning pada pakaian. Oleh karena itu menurut PP No.20 Tahun 1990 tersebut, kadar (Fe) dalam air minum maksimum yang dibolehkan adalah 0,3 $\mathrm{mg} / \mathrm{lt}$, dan kadar Mangan (Mn) dalam air minum yang dibolehkan adalah $0,1 \mathrm{mg} / \mathrm{lt}$.

Permasalahan yang sering timbul saat ini adalah banyak kawasan pemukiman yang telah dibangun di dalam kawasan yang kualitas air tanahnya tidak dapat digunakan sebagai sumber air minum misalnya airnya mengandung zat besi atau mangan dengan konsentrasi yang cukup tinggi atau merupakan kawasan yang air tanahnya payau. Dilain pihak pelayanan air bersih atau suplai air dari PAM setempat belum ada. Akibatnya masyarakat harus memenuhi air untuk kebutuhan minum dengan cara membeli air minum kemasan dengan harga yang sangat mahal yakni sekitar Rp. 6000,- sampai Rp, 8000,- per 20 liter. Dengan demikian maka kondisi tersebut sangat memberatkan masyakarat khusunya masyarakat miskin.

Dalam rangka mengatasi permasalahan tersebut di atas, perlu mengembangkan paket teknologi untuk mengolah air tanah, air sumur atau air PAM menjadi air yang dapat langsung diminum tanpa dimasak terlebih dahulu. Unit alat tersebut terdiri dari antara lain : pompa air baku, filter pasir, filter mangan zeolit, filter karbon aktif, cartridge filter, sterilisator ultra violet dan ozon generator. Unit alat tersebut dapat dirancang dalam bentuk paket yang kompak dan sederhana disesuaikan dengan kondisi sosial ekonomi masyarakat dengan kapasitas olah dapat disesuaikan dengan kebutuhan suatu wilayah yang diinginkan.

\section{PROSES PENGOLAHAN DAN SPESIFIKASI TEKNIS ALAT}

\subsection{PROSES PENGOLAHAN}

Pada umumnya kualitas air sumur atau air tanah mempunyai karakteristik yang berbeda dengan kualitas air permukaan/ sungai. Air tanah pada umumnya jernih,namun sering mengandung mineral-mineral atau garam-garam yang cukup tinggi, sebagai akibat dari pengaruh batuan dibawah tanah yang dilalui oleh air tanah. Pada air tanah dangkal, kualitas dan kuantitasnya dipengaruhi oleh kondisi lingkungan di permukaanya, dalam hal kuantitas sangat dipengaruhi oleh curah hujan setempat, sementara kualitasnya dipengaruhi oleh kondisi sanitasi disekitarnya.

Proses pengolahan air sumur atau air PAM menjadi air yang siap minum, seperti ditunjukkan pada Gambar 1. Air dari sumur atau air yang berasal dari PAM dipompa dengan menggunakan pompa semi jet, sambil diinjeksi dengan larutan kaporit atau kalium permanganat dengan konsentrasi disesuaikan dengan kualitas air baku, selanjutnya dialirkan ke tangki reaktor untuk menyempurnakan reaksi dengan memberikan waktu tinggal untuk terjadinya reaksi oksidasi.

Setelah air melalui tangki reaktor air dialirkan ke saringan pasir cepat untuk menyaring oksida besi atau oksida mangan yang terbentuk di dalam tangki reaktor. Setelah disaring dengan saringan pasir, air dialirkan ke filter mangan zeolit untuk menghilangkan zat besi atau mangan yang belum sempat teroksidasi oleh khlorine atau kaporit. Dari filter mangan zeolit air selanjutnya dialirkan ke filter karbon aktif untuk menghilangkan polutan mikro misalnya zat organik, deterjen, bau, senyawa phenol, logam berat dan lain-lain. Setelah melalui filter karbon aktif air dialirkan ke filter cartrige ukuran 0,5 mikron untuk menghilangkan sisa partikel padatan yang ada di dalam air, sehingga air menjadi benar-benar jernih.

Proses lanjutan untuk menjamin air produk bebas dari bakteri dan mikroorganisme yang merugikan, air dialirkan ke sterilisator ultra violet dan disempurnakan lagi dengan ozon generator, dengan injeksi ozon setelah filter cartridge

Air yang keluar dari sterilsator ozon dan ultra violet merupakan air hasil olahan yang memenuhi peryaratan sebagai air minum dan dapat langsung diminum.

\section{A. INJEKSI KAPORIT/KHLORINE}

Injeksi atau pembubuhan kaporit bertujuan untuk mengoksidasi zat besi atau mangan yang ada di dalam air, serta untuk membunuh kuman atau bakteri coli. Reaksi oksidasi besi atau mangan oleh khlorine atau kaporit adalah sebagai berikut :

$$
\begin{array}{ll}
2 \mathrm{Fe}^{2+}+\mathrm{Cl}_{2}+6 \mathrm{H}_{2} \mathrm{O}==> & \begin{array}{l}
2 \mathrm{Fe}(\mathrm{OH})_{3}+2 \mathrm{Cl}^{-}+ \\
6 \mathrm{H}^{+}
\end{array} \\
\mathrm{Mn}^{2+}+\mathrm{Cl}_{2}+2 \mathrm{H}_{2} \mathrm{O}==> & \mathrm{MnO}_{2}+2 \mathrm{Cl}^{-}+4 \mathrm{H}^{+}
\end{array}
$$

Khlorine, $\mathrm{Cl}_{2}$ dan ion hipokhlorit, $(\mathrm{OCl})^{-}$adalah merupakan bahan oksidator yang kuat sehingga meskipun pada kondisi $\mathrm{Ph}$ rendah dan oksigen terlarut sedikit, dapat mengoksidasi dengan cepat. Berdasarkan reaksi tersebut di atas, maka untuk mengoksidasi setiap $1 \mathrm{mg} / \mathrm{l}$ zat besi dibutuhkan 0,64 mg/l khlorine dan setiap $1 \mathrm{mg} / \mathrm{l}$ mangan dibutuhkan 1,29 mg/l khlorine. Tetapi pada prakteknya, pemakaian khlorine ini lebih besar dari kebutuhan teoritis karena adanya reaksi-reaksi samping yang mengikutinya.

Injeksi khlorine dilakukan dengan
menggunakan maksimun sekitar 4,7 liter per jam. Laju injeksi 
dapat diatur dengan cara mengatur jumlah stroke yang ada pada pompa dosing. Konsentrasi khlorine yang masuk ke static mixer dan tangki reaktor diatur kira-kira 0,1 ppm. Diagram pembubuhan khlorine dapat dilihat seperti pada Gambar 2 .

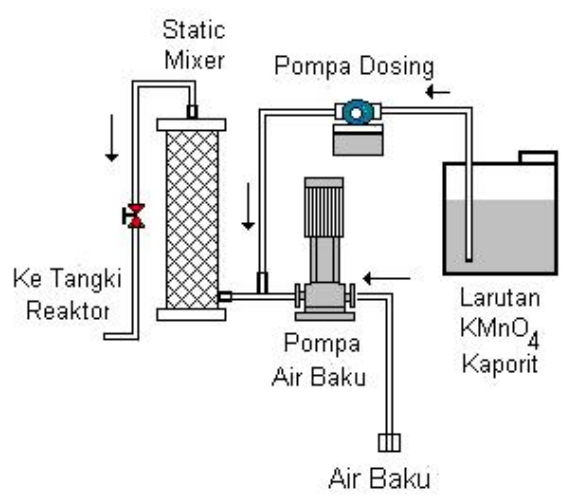

Gambar 2 : Skema injeksi larutan Kaporit.

\section{B. SARINGAN PASIR DAN SARINGAN MANGAN ZEOLIT}

Air yang telah melewati tangki reaktor dialirkan ke filter pasir yang diisi dengan pasir silika dan gravel. Media pasir silika berfungsi untuk untuk menyaring padatan yang ada di dalam air serta oksida besi atau oksida mangan yang terbentuk di dalam tangki reaktor.

Bahan media terdiri dari Batu kerikil kasar, kerikil halus, pasir silika kasar dan pasir silika halus. Skema susunan media yang ada di dalam filter pasir ditunjukkan seperti pada Gambar 3.

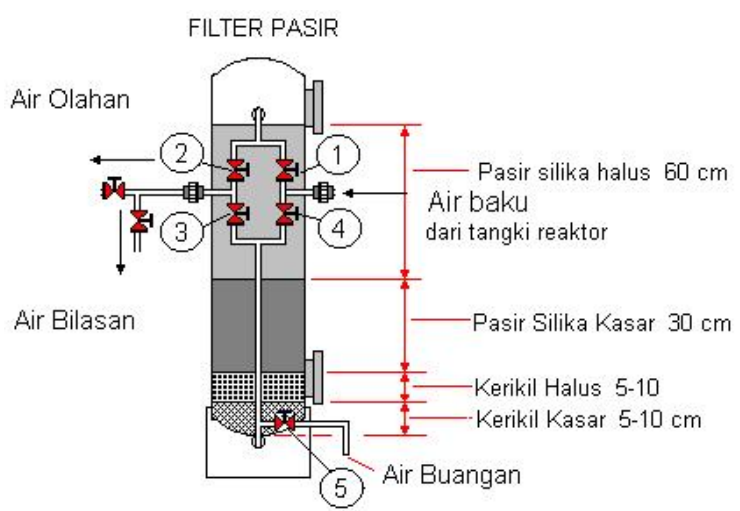

Gambar 3 : Susunan media di dalam filter pasir

Susunan media dari bawah ke atas adalah sebagai berikut :

- Lapisan kerikil kasar $\quad=5-10 \mathrm{~cm}$

- Lapisan kerikil halus $\quad=5-10 \mathrm{~cm}$

- Lapisan pasir silika kasa $=30 \mathrm{~cm}$

- Lapisan pasir silika halus $=60 \mathrm{~cm}$
Cara pengoperasian filter pasir ditunjukkan seperti pada Gambar 4.

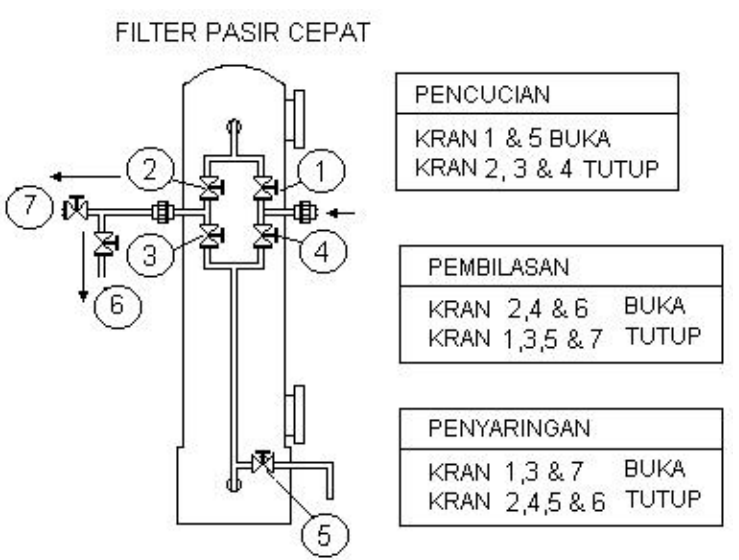

Gambar 4 : Diagram proses pengoperasian unit Filter Pasir

Filter mangan zeolit berfungsi untuk menghilangkan zat besi atau mangan yang belum sempat teroksidasi oleh khlorine atau kaporit. Mangan Zeolit berfungsi sebagai katalis dan pada waktu yang bersamaan besi dan mangan yang ada dalam air teroksidasi menjadi bentuk ferri-oksida dan mangandioksida yang tak larut dalam air.

Reaksinya adalah sebagai berikut :

$\mathrm{K}_{2} \mathrm{Z} \cdot \mathrm{MnO} \cdot \mathrm{Mn}_{2} \mathrm{O}_{7}+4 \mathrm{Fe}\left(\mathrm{HCO}_{3}\right)_{2}==>\mathrm{K}_{2} \mathrm{Z}+$

$3 \mathrm{MnO}_{2}+2 \mathrm{Fe}_{2} \mathrm{O}_{3}+8 \mathrm{CO}_{2}+4 \mathrm{H}_{2} \mathrm{O}$

$\mathrm{K}_{2} \mathrm{Z} \cdot \mathrm{MnO} \cdot \mathrm{Mn}_{2} \mathrm{O}_{7}+2 \mathrm{Mn}\left(\mathrm{HCO}_{3}\right)_{2}==>\mathrm{K}_{2} \mathrm{Z}+$ $5 \mathrm{MnO}_{2}+4 \mathrm{CO}_{2}+2 \mathrm{H}_{2} \mathrm{O}$

Reaksi penghilangan besi dan mangan dengan mangan zeoilte tidak sama dengan proses pertukaran ion, tetapi merupakan reaksi dari $\mathrm{Fe}^{2+}$ dan $\mathrm{Mn}^{2+}$ dengan oksida mangan tinggi (higher mangan oxide). Filtrat yang terjadi mengandung ferri-oksida dan mangan-dioksida yang tak larut dalam air dan dapat dipisahkan dengan pengendapan dan penyaringan. Selama proses berlangsung kemampunan reaksinya makin lama makin berkurang dan akhirnya menjadi jenuh. Untuk regenerasinya dapat dilakukan dengan menambahkan larutan Kaliumpermanganat ke dalam mangan zeolite yang telah jenuh tersebut sehingga akan terbentuk lagi mangan zeolite $\left(\mathrm{K}_{2} \mathrm{Z} \cdot \mathrm{MnO} \cdot \mathrm{Mn}_{2} \mathrm{O}_{7}\right)$.

Bahan media terdiri dari Batu kerikil kasar, kerikil halus, pasir silika kasar, pasir silika halus dan mangan zeolit. Skema susunan media yang ada di dalam filter Mangan Zeolit ditunjukkan seperti pada Gambar 5. Susunan media dari bawah ke atas adalah sebagai berikut 
- Lapisan kerikil kasar

- Lapisan kerikil halus

$=5-10 \mathrm{~cm}$

$=5-10 \mathrm{~cm}$

- Lapisan pasir silika kasa $=10 \mathrm{~cm}$

- Lapisan pasir silika halus $=30 \mathrm{~cm}$

- Lapisan mangan zeolit = $40 \mathrm{~cm}$ Cara pengoperasian filter mangan zeolit ditunjukkan seperti pada Gambar 6.

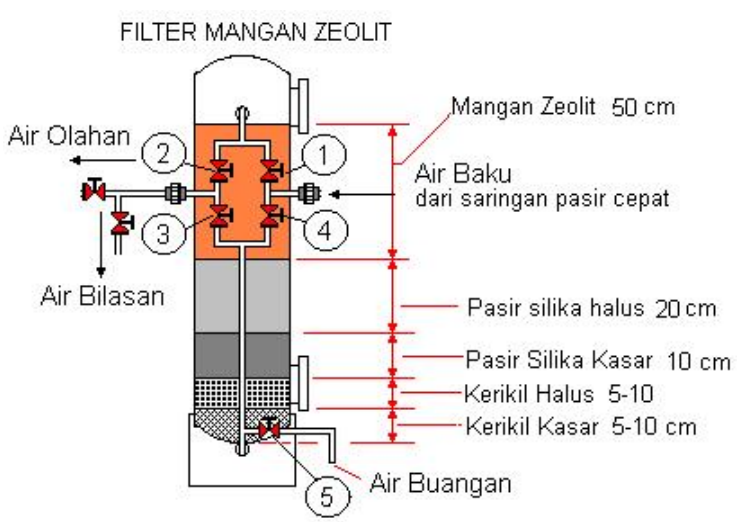

Gambar 5 : Susunan media di dalam filter Mangan Zeolit.

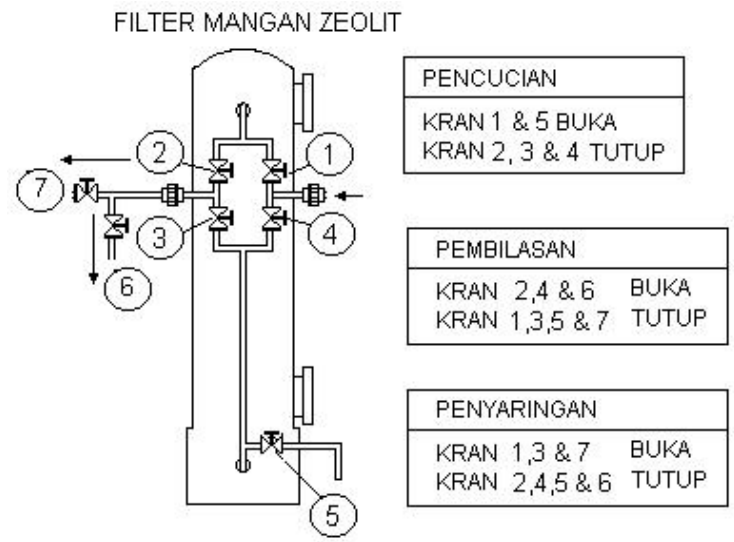

Gambar 6 : Diagram proses pengoperasian unit filter mangan zeolit.

\section{SARINGAN KARBON AKTIF}

Air yang telah terproses dalam filter mangan zeolit selanjutnya dialirkan ke filter karbon aktif. Filter karbon aktif ini berfungsi untuk menghilangkan polutan mikro misalnya zat organik, deterjen, bau, senyawa phenol serta untuk menyerap logam berat dan lain-lain.

Dalam saringan karbon aktif ini terjadi proses adsorpsi, yaitu proses penyerapan zatzat yang akan dihilangkan oleh permukaan arang aktif. Apabila seluruh permukaan karbon/ arang aktif sudah jenuh, atau sudah tidak mampu lagi menyerap maka proses penyerapan akan berhenti, dan pada saat ini karbon aktif harus diganti dengan karbon aktif yang baru.

Susunan media yang ada di dalam filter karbon aktif ditunjukkan seperti pada Gambar 7, sedangkan skema proses pengoperasian filter karbon aktif ditunjukkan seperti pada Gambar 8. Susunan media dari bawah ke atas adalah sebagai berikut :

- Lapisan kerikil kasar $\quad=5-10 \mathrm{~cm}$

- Lapisan kerikil halus $\quad=5-10 \mathrm{~cm}$

- Lapisan pasir silika kasar $=10 \mathrm{~cm}$

- Lapisan pasir silika halus $=10 \mathrm{~cm}$

- Lapisan karbon aktif $\quad=60 \mathrm{~cm}$

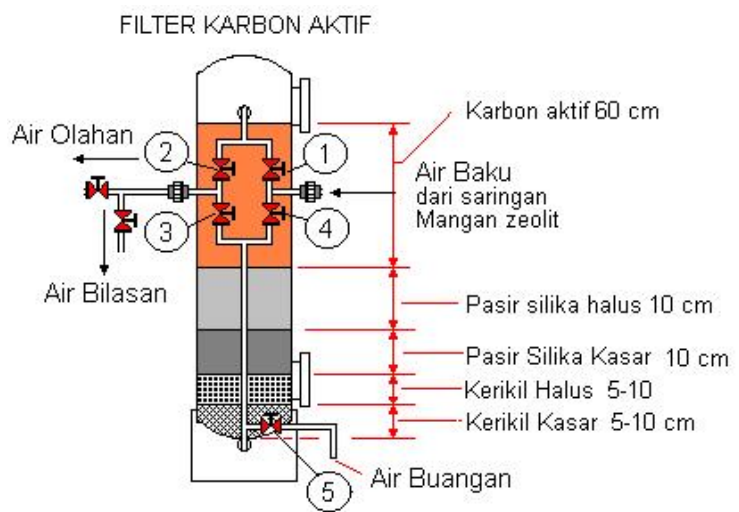

Gambar 7 : Susunan media di dalam filter karbon aktif.

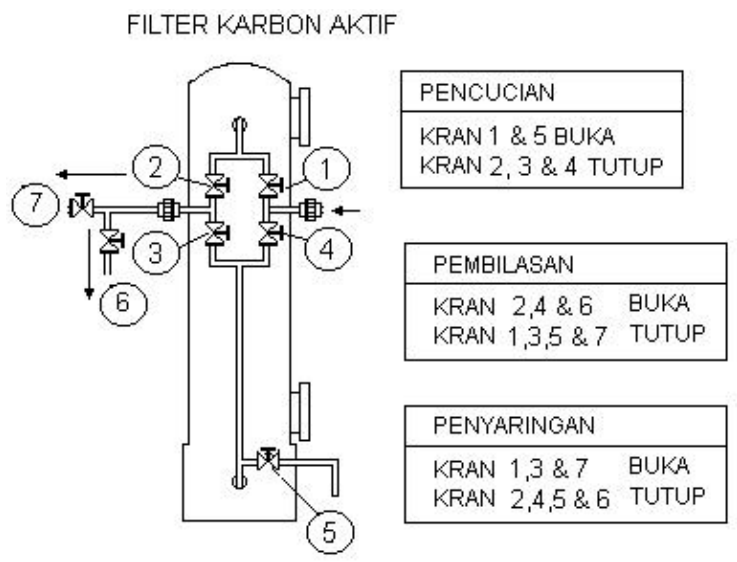

Gambar 8 : Skema pengopersian filter karbon aktif.

\section{PENGHILANGAN KESADAHAN DENGAN PROSES PERTUKARAN ION}

Pada kasus tertentu dimana air baku mengandung kesadahan, diperlukan peralatan tambahan dengan fungsi sebagai pertukaran ion (Ion Exchange). Pada proses pertukaran ion, kalsium dan magnesium ditukar dengan sodium. Pertukaran ini berlangsung dengan cara melewatkan air sadah ke dalam unggun butiran yang terbuat dari bahan yang mempunyai kemampuan menukarkan ion. Bahan penukar ion pada awalnya menggunakan bahan yang berasal dari alam yaitu greensand yang biasa disebut zeolit, Agar lebih efektif Bahan 
greensand diproses terlebih dahulu. Disamping itu digunakan zeolit sintetis yang terbuat dari sulphonated coals dan condentation polymer. Pada saat ini bahan-bahan tersebut sudah diganti dengan bahan yang lebih efektif yang disebut resin penukar ion. Resin penukar ion umumnya terbuat dari partikel cross-linked polystyrene. Terdapat beberapa resin penukar ion yang diproduksi oleh berbagai pabrik dan dipasaran masing-masing mempunyai nama dagang tersendiri.

Untuk proses penghilangan kesadahan atau pelunakan, resin yang digunakan adalah resin penukar kation yang mengandung sodium, pada proses ini ion Na pada resin ditukar dengan ion $\mathrm{Ca}$ dan $\mathrm{Mg}$ yang terdapat pada air yang diolah. Selama proses pelunakan, lama kelamaan ion $\mathrm{Na}$ akan habis ditukar dengan ion $\mathrm{Ca}$ dab $\mathrm{Mg}$, pada saat ini resin tersebut dikatakan telah jenuh, dan sudah tidak berfungsi lagi. Apabila resin telah jenuh maka resin tersebut perlu diregenerasi. Proses regenerasi dilakukan dengan cara melewatkan larutan garam dapur pekat ke dalam unggun resin yang telah jenuh. Pada proses regenerasi terjadi reaksi sebaliknya yaitu kalsium dan magnesium dilepaskan dari resin, digantikan dengan sodium dari larutan garam.

Reaksi pelunakan adalah sebagai berikut :

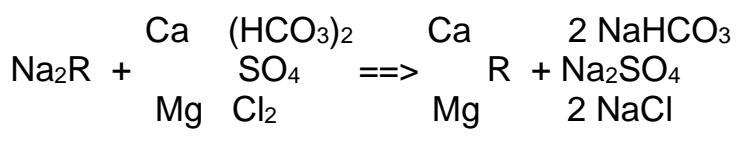

Reaksi regenerasi adalah sebagai berikut :

$$
\mathrm{Mg} \mathrm{R}+2 \mathrm{NaCl}===>\mathrm{Na}_{2} \mathrm{R}+{ }_{\mathrm{Mg}}^{\mathrm{Ca}} \mathrm{Cl}_{2}
$$

Susunan media di dalam filter penukar ion (softener) adalah sebagai berikut :

- Lapisan kerikil kasar $\quad=5-10 \mathrm{~cm}$

- Lapisan kerikil halus $\quad=5-10 \mathrm{~cm}$

- Lapisan pasir silika kasar $=10 \mathrm{~cm}$

- Lapisan pasir silika halus $=10 \mathrm{~cm}$

- Lapisan penukar ion $\quad=80-00 \mathrm{~cm}$

Sedangkan skema pengoperasian filter penukar ion ditunjukkan pada Gambar 9.

Regenerasi resin penukar ion dilakukan dengan membubuhkan larutan garam dapur (10 $\%$ ) ke dalam filter penukar ion. Larutan garam dapur dibuat dengan cara memasukkan $5 \mathrm{~kg}$ garam dapur ke dalam tangki garam dan dilarut kan dengan 50 liter air, lalu diaduk sampai larut. Dengan melakukan tahapan proses regenerasi seperti pada Gambar 9, maka injektor akan terjadi vakum dan akan menghisap larutan garam ayang ada di dalam tangki garam dan masuk ke dalam filter penukar ion. Proses regenerasi dilakukan kira-kira 10-20 menit.

\section{E. CARTRIDGE FILTER}

Setelah disaring memlalui filter penukar ion (Softener), air dialirkan melalui filter cartridge untuk menghilangkan kekeruhan yang mungkin masih tersisa. Filter cartridge ini dapat menyaring padatan atau kekeruhan sampai ukuran 0,5 mikron. Dengan demikian air yang keluar dari cartridge filter ini sudah sangat jernih.

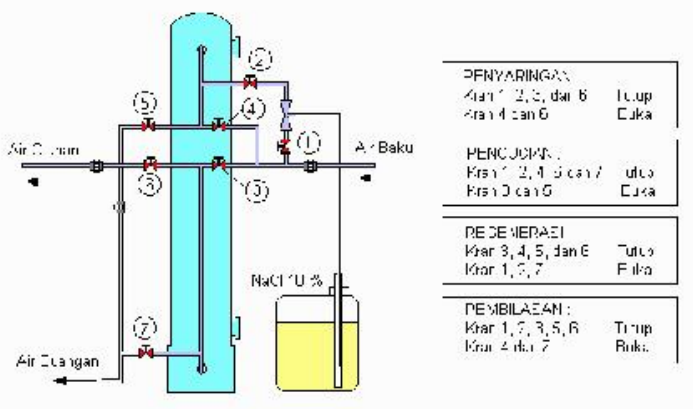

Gambar 9 : Skema pengoperasian filter penukar ion (softener).

\section{F. STERILISATOR ULTRA VIOLET}

Air proses dari cartridge filter, selanjutnya air dialirkan ke sterilisator ultra violet agar seluruh bakteri atau mikroorganisme yang ada di dalam air dapat dibunuh secara sempurna. Air yang keluar dari sterilsator ultra violet merupakan air hasil olahan yang dapat langsung diminum.

\section{G. OZON GENERATOR}

Penyempurnaan sterilisasi air yang telah diproses dilanjutkan dengan injeksi ozon yang dihasilkan oleh generator ozon, setelah itu air hasil olahan ditampung di bak penampung yang terbuat dari stainlees-steel, selanjutnya dibagi melalui kran distribusi di tempat pengisiian.

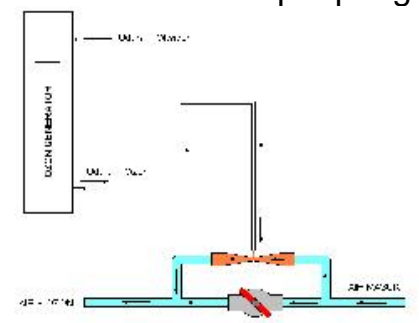

Gambar 10: Skema Injeksi Ozon

\subsection{SPESIFIKASI PERALATAN}

\section{A. POMPA AIR BAKU}

Type : Jet/Semi Jet 


$\begin{array}{ll}\text { Power } & : 250 \text { Watt } \\ \text { Pressure } & : 4 \text { Bars (max) } \\ \text { Suction Head } & : 9 \mathrm{~m} \\ \text { Jumlah } & : 1 \text { unit }\end{array}$

\section{B. Pompa dosing}

\begin{tabular}{ll} 
Type & $:$ Chemtech 100/030 \\
Tekanan & $: 7$ Bars \\
Kapasitas & $: 4.7 \mathrm{lt} /$ hour \\
Pump head & $:$ SAN \\
Diaphragm & $:$ Hypalon \\
Jumlah & $: 1$ unit \\
\multicolumn{1}{c}{ Tangki Bahan Kimia } \\
Volume & $: 25$ liter \\
Ukuran & $: 50 \mathrm{~cm} \times 25 \mathrm{~cm} \times 10 \mathrm{~cm}$ \\
Material & $:$ Fiberglass Reinforced \\
& Plastic (FRP) \\
Jumlah & $: 1$ unit
\end{tabular}

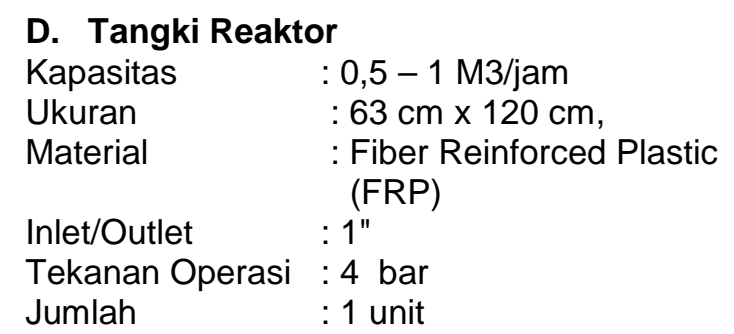

\section{E. Saringan Pasir (Sand Filter)}

$\begin{array}{ll}\text { Tekanan } & : \text { B Bars } \\ \text { Capacity } & : 1.4-1.8 \mathrm{~m} 3 / \text { jam } \\ \text { Ukuran } & : \varnothing 12 \text { inchi x } 120 \mathrm{~cm} \\ \text { Material } & : \text { FRP/ PVC/ SS } \\ \text { Pipa Inlet / outlet } & : \text { 3/4 inch } \\ \text { System } & : \text { manual backwash } \\ \text { Media Filter } & : \text { Pasir Silika } \\ \text { Media Penahan } & : \text { Gravel } \\ \text { Number } & : 1 \text { unit }\end{array}$

\section{F. Filter mangan Zeolit}

$\begin{array}{ll}\text { Tekanan } & : \text { 3 Bars } \\ \text { Capacity } & : 1.4-1.8 \mathrm{m3} / \text { jam } \\ \text { Ukuran } & : \varnothing 12 \text { inchi } \times 120 \mathrm{~cm} \\ \text { Material } & : \text { FRP/ PVC/ SS } \\ \text { Pipa Inlet / outlet } & : 3 / 4 \text { inch } \\ \text { System } & : \text { manual backwash } \\ \text { Media Filter } & : \text { Mangan Zeolit } \\ \text { Media Penahan } & : \text { Gravel } \\ \text { Number } & : 1 \text { unit } \\ & \\ \text { G. Filter Karbon } & \text { Aktif } \\ \text { Tekanan } & : 3 \text { Bars } \\ \text { Capacity } & : 1.4-1.8 \mathrm{~m} 3 / \text { jam } \\ \text { Ukuran } & : \varnothing 10 \text { inchi } \times 120 \mathrm{~cm} \\ \text { Material } & : \text { FRP/ PVC/ SS } \\ \text { Pipa Inlet / outlet } & : 3 / 4 \text { inch } \\ \text { System } & : \text { manual backwash } \\ \text { Media Filter } & : \text { Karbon Aktif Granular } \\ \text { Media Penahan } & : \text { Gravel }\end{array}$

$\begin{array}{ll}\text { Number } & : 1 \text { unit } \\ & \\ \text { H. Filter Penukar lon } \\ \text { Tekanan } & : 3 \text { Bars } \\ \text { Capacity } & : 1.4-1.8 \mathrm{~m} 3 / \text { jam } \\ \text { Ukuran } & : \varnothing 10 \mathrm{inchi} \times 120 \mathrm{~cm} \\ \text { Material } & : \text { FRP/ PVC/ SS } \\ \text { Pipa Inlet / outlet } & : 3 / 4 \text { inch } \\ \text { System } & : \text { manual backwash } \\ \text { Media Filter } & : \text { Resin Kation Exchange } \\ \text { Media Penahan } & : \text { Gravel } \\ \text { Number } & : 1 \text { unit }\end{array}$

\section{Filter Cartridge}

Tipe : Proklean PK-CP-1

$\begin{array}{ll}\text { Kapasitas } & : 20 \mathrm{Liter} / \text { menit } \\ \text { Tekanan mak } & : 125 \mathrm{Psi} \\ \text { Inlet/Outlet } & : 3 / 4 \text { " } \\ \text { Diameter pore } & : 0,5 \text { mikron }\end{array}$

\section{J. Sterilisator Ultra Violet}

$\begin{array}{ll}\text { Kapasitas } & : 10-20 \text { ton/day } \\ \text { Power } & : 30 \text { watt } \\ \text { Jumlah } & : 1 \text { unit }\end{array}$

\section{J. Ozon Generator \\ Tipe \\ Tinggi \\ Lebar \\ Tebal \\ Power
: OXOMATIC - MOG 20
: $590 \mathrm{~mm}$
: $155 \mathrm{~mm}$
$: 80 \mathrm{~mm}$ \\ : 240 Volt, 85 - 105 watt}

\section{UJI COBA ALAT}

Percontohan untuk pemasyarakatan unit pengolahan air siap minum dengan kapasitas $10.000-20.000$ liter per hari telah dibangun di Kelurahan Cikini RW 8 Jakarta Pusat.

Air baku yang akan diolah diambil dari air PAM dengan yang ditampung di dalam bak penampung air baku dengan kapasitas $8 \mathrm{~m}^{3}$.

Dalam rangka uji coba unit pengolahan air siap minum, sebelum unit ini dioperasikan, tahap pertama yang dilakukan adalah pencucian filter pasir, selanjutnya diikuti dengan pencucian filter mangan zeolit dan filter karbon. Unit percontohan di Kelurahan Cikini ini tidak dilengkapi dengan filter penukar ion karena air baku tidak mengandung kesadahan, sehingga tidak dilakukan pengaktifan filter penukar ion. Air pencuci yang digunakan adalah air baku dari bak penampung sambil diinjeksi larutan kaporit dengan konsentrasi diatur sekitar $0,5 \mathrm{mg} / \mathrm{l}$. Hal ini dilakukan agar bakteria yang ada di dalam media penyaring dapat dimatikan. Setelah bersih, injeksi kaporit di kecilkan dan diatur menjadi sekitar $0,2 \mathrm{mg} / \mathrm{l}$. Selanjutnya filter dibilas satu persatu mulai dari filter pasir, filter filter 
mangan zeolit dan filter karbon aktif. Setelah proses pembilasan filter pasir, filter mangan zeolit dan filter karbon aktif sempurna, unit pengolahan air siap minum dapat dioperasikan.

Larutan khlorine diatur dengan konsentrasi kaporit di dalam air baku mencapai kira-kira 0,2 $\mathrm{mg} / \mathrm{l}$. Setelah diinjeksi dengan larutan kaporit, air masuk ke Static Mixer, Tangki Reaktor, FilterPasir, Filter Mangan Zeolit, filter cartridge, selnjutnya masuk ke strilisator Ultra Violet, dan terakhir masuk ke ejektor vakum yang berhubungan dengan generator ozon, sehingga air akan bercampur dengan udara yang mengandung ozon yang dihasilkan dari generator ozon. Air yang telah bercampur dengan ozon selanjutnya ditampung di dalam bak penampung yang terbuat dari bahan stainless steel. Dari bak penampung air olahan selanjutnya air dialirkan ke ruang pengisian.

Pada saat awal proses, air olahan dibuang yang dihasilkan dibuang untuk beberapa waktu yakni sekitar 8 jam. Hal ini dilakukan untuk proses pembersihan perpipaan dan bak penampung, serta untuk meng-hilangkan bau lem yang terdapat pada perpipaan. Setelah proses berjalan stabil air olahan ditampung di dalam bak penampung air olahan, dan selajutnya dilairkan ke unit pengisian.

Setelah proses berjalan konstan atau kirakira tiga hari operasi sampel air olahan diambil dan dianalisa di laboratorium untuk diperiksa parameter fisika-kimia dan parameter bakteriologisnya. Pemeriksaan dilakukan di laboratorium Sucofindo Jakarta. Hasil analisa selengkapnya dapat dilihat seperti pada Tabel 1. Berdasarkan hasil analisa tersebut air olahan yang telah dihasilkan layak digunakan sebagai air siap minum, artinya telah memenuhi syarat sebagai air yang dapat langsung diminum tanpa dimasak terlebih dahulu.

\section{ANALISA EKONOMI ALAT}

Unit pengolahan air siap minum ditempatkan di kelurahan Cikini Jakarta Pusat ini berkapasitas 10.000 - 20.000 liter per hari ditempatkan dalam bangunan pelindung dengan luas $12 \mathrm{~m}^{2}$ lengkap dengan electrical pendukung. Unit alat tersebut di kelola oleh masyarakat setempat dengan pengawasan dan bimbingan pihak kelurahan Cikini Jakarta Pusat. Air hasil olahan di jual ke masyarakat setempat dengan harga sekitar Rp. 2.500,- (dua ribu lima ratus rupiah) tiap satu galon akua (20 liter) dan diantar sampai ke rumah.

Biaya investasi satu unit alat pengolahan air siap minum kapasitas 20.000 liter per hari termasuk bangunan pelindung adalah Rp.100.000.000,- (Seratus juta rupiah). Harga belum termasuk harga tanah.

\subsection{Biaya Produksi}

Biaya Produksi per tahun adalah seperti pada tabel berikut :

\begin{tabular}{|c|l|r|}
\hline No & Jenis Pengeluaran & $\begin{array}{c}\text { Total } \\
\text { Pengeluaran } \\
(\mathrm{Rp})\end{array}$ \\
\hline 1 & Biaya Listrik \& PAM & 900.000 \\
\hline 2 & $\begin{array}{l}\text { Bahan Kimia Kalium } \\
\text { Permanganat/Kaporit }\end{array}$ & 200.000 \\
\hline 3 & Media Filter & 3.000 .000 \\
\hline 4 & Cartirdge Filter & 300.000 \\
\hline 5 & $\begin{array}{l}\text { Biaya operator }(2 \\
\text { orang) }\end{array}$ & 9.600 .000 \\
\hline 6 & Lampu UV & 300.000 \\
\hline 7 & Lampu Ozon & 25.200 .000 \\
\hline 8 & Lain-lain & 42.750 .000 \\
\hline & Biaya air Baku & $\begin{array}{l}\text { Total biaya produksi } \\
\text { per tahun }\end{array}$ \\
\hline
\end{tabular}

\subsection{Skenario Pendapatan}

Total Produksi maksimum per tahun (320 hari kerja) $=10.000$ Lt/hari $X 320$ Hari $=$ 3.200.000 Liter

Biaya produksi air siap minum $=$ Rp. 13,35 per liter

Harga Jual = Rp. 2500,- per 20 Liter.

\section{Skenario Terjual 50 \% Dari Kapasitas Produksi :}

Asusmsi :Terjual $50 \%$ dari kapasitas produksi.

Pendapatan kotor per tahun $=3.200 .000 / 20 X$ 0,5 X Rp. 2500,- = Rp. 200.000.000,-

Pendapatan per tahun $=$ Rp.200.000.000 - Rp. 42.750.000 = Rp. 157.250.000,-

( Jika tanpa memperhitungkan modal).

\section{Skenario Terjual $25 \%$ Dari Kapasitas Produksi :}

Asusmsi :Terjual $25 \%$ dari kapasitas produksi.

Pendapatan kotor per tahun $=3.200 .000 / 20 \mathrm{X}$ 0,25 X Rp. 2500,- = Rp. 100.000.000,-

Pendapatan per tahun $=$ Rp.100.000.000 - Rp. 42.750.000 = Rp. 57.250.000,-

(tanpa memperhitungkan modal).

\section{KESIMPULAN}


Untuk mengolah air tanah atau air PAM menjadi air yang siap minum dapat dilakukan dengan proses yang komplit namun dapat dikemas dengan sistem yang sederhana dan mudah dioperasikan. Sistem pengolahan air siap minum ini merupakan kombinasi proses oksidasi dengan kalium permanganat atau khlorine, penyaringan dengan filter pasir, filter mangan zeolit dan karbon aktif dan dilengkapi dengan sistem disinfeksi dengan menggunakan UV sterilisator dan injeksi dengan ozon.

Unit alat pengolahan air siap minum tersebut sangat berpotensi sebagai usaha industri kecil pengisian kembali air kemasan galon karena biaya produksinya sangat rendah dan untuk daerah padat penduduk yang sulit air bersih siap minum, sehingga hal tersebut mempunyai nilai ekonomi yang tinggi.

Unit alat pengolahan air siap minum ini sangat cocok digunakan untuk berbagai keperluan misalnya :

- Pemukiman padat penduduk.

- Daerah pemukiman yang kualitas air tanahnya buruk

- Asrama, sekolah, pesantren

- Komplek pemukiman, industri dan perkantoran

- DII.

\section{DAFTAR PUSTAKA}

- Asaoka Tadatomo, "Yousui Haisui Shori Gijutsu ", Tokyo, 1973.

- Benefiled, L.D., Judkins, J.F., and Weand, B.L., "Process Chemistry For Water And Waste Treatment", Prentice-Hall, Inc., Englewood, 1982.

- Fair, G.M., Geyer, J.C., AND Okun, D.A., " Element Of Water Supply And Waste Water Disposal ", Second Edition, John Wiley And Sons, New York, 1971.

- Hamer, M. J., " Water And Waste water Technology ", Second Edition, John Wiley And Sons, New York, 1986.

- Peavy, H.S., Rowe, D.R, AND Tchobanoglous, S.G., "Environmental Engineering ", Mc Graw-Hill Book Company, Singapore, 1986.

- R. Hening Darpito SKM. Dipl., SE, dkk, 1995," Materi Pelatihan Penyehatan Air", Departemen Kesehatan RI, Dir-Jen PPM \& PLP, Jakarta 110-119

- Tatsumi Iwao, " Water Work Engineering (JOSUI KOGAKU) ", Japanese Edition, Tokyo, 1971.

- Viessman W,JR., "Water Supply And Pollution Control ", fourth edition, Harper and Ror Publisher, New york, 1985. 


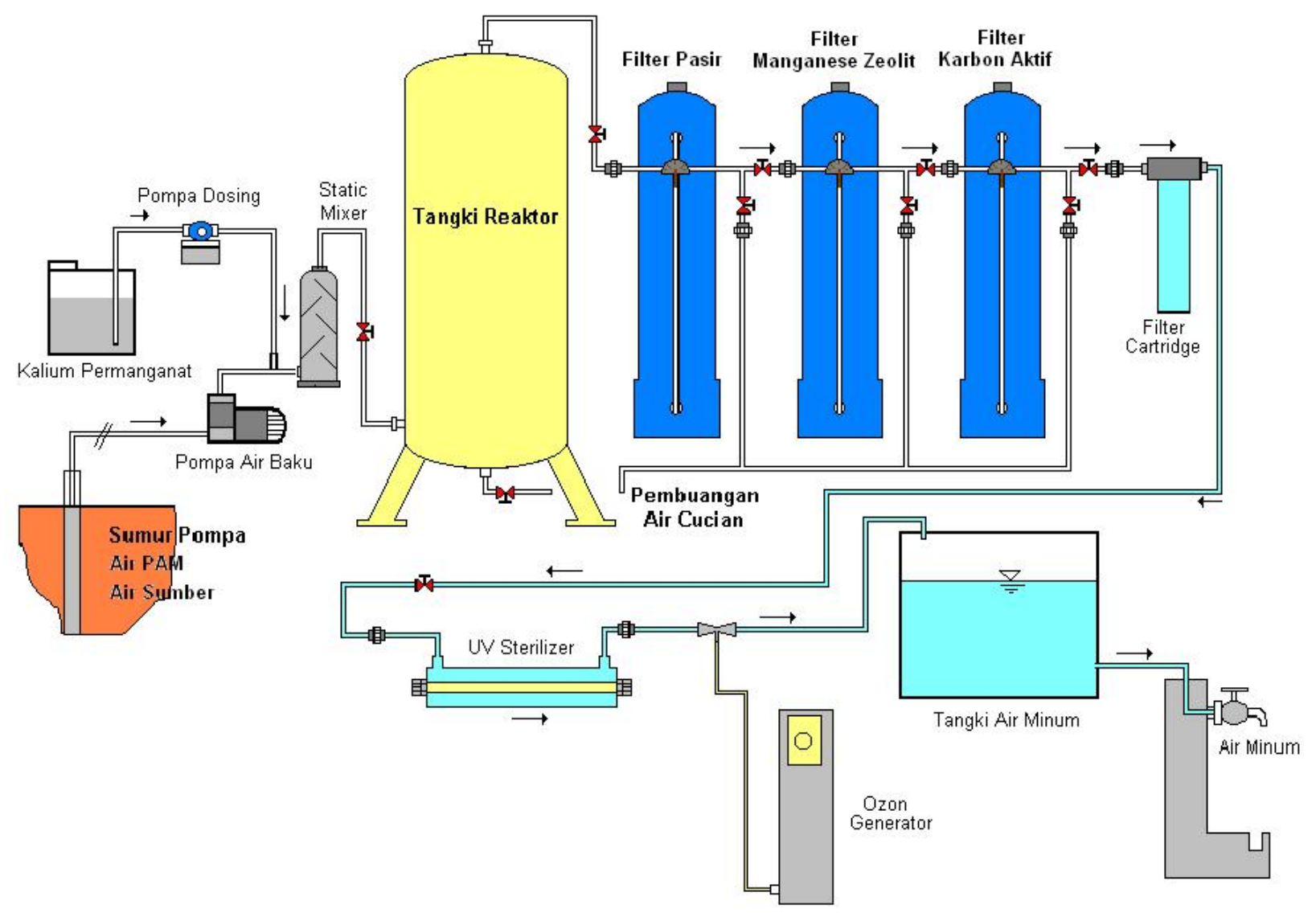

Gambar 1 : Diagram proses pengolahan air sumur siap mnum. 
Tabel 1 : Hasil Analisa Kualitas Air Olahan Unit Pengolahan Air Siap Minum

\begin{tabular}{|c|c|c|c|c|c|}
\hline \multicolumn{2}{|c|}{ Parameter } & \multirow[t]{2}{*}{ Unit } & \multirow[t]{2}{*}{ Test Results } & \multirow{2}{*}{$\begin{array}{c}\text { Requirement } \\
\text { SNI 01-3553- } \\
1996\end{array}$} & \multirow{2}{*}{$\begin{array}{c}\text { Method }{ }^{\star} \text { ) } \\
\text { Part Number }\end{array}$} \\
\hline 1 & Organoleptic: & & & & \\
\hline & 1.1 Odor & - & Negativ & Odorless & $2150 \mathrm{~B}$ \\
\hline & 1.2 Taste & - & Normal & Tasteless & $2160 \mathrm{C}$ \\
\hline & 1.3 Color & $\begin{array}{l}\text { Pt Co } \\
\text { scale }\end{array}$ & Nil & 2.5 & $2120 \mathrm{~B}$ \\
\hline \multirow[t]{21}{*}{2} & $\begin{array}{l}\text { Physical \& chemical } \\
\text { : }\end{array}$ & & & & \\
\hline & $2.1 \mathrm{PH}$ & - & 7.25 & $6.5-8.5$ & $4500-\mathrm{H}^{+}-\mathrm{B}$ \\
\hline & 2.2 Turbidity & NTU & Nil & 5 & $2130 \mathrm{~B}$ \\
\hline & $\begin{array}{l}2.3 \text { Total Hardness } \\
\text { as } \mathrm{CaCO}_{3}\end{array}$ & $\mathrm{mg} / 1$ & 0.95 & 170 & $2340 \mathrm{C}$ \\
\hline & 2.4 Dissolved Solid & $\mathrm{mg} / 1$ & 300 & 500 & $2540 \mathrm{~B}$ \\
\hline & $\begin{array}{l}2.5 \text { Organic Meter } \\
\text { by } \mathrm{KmnO}_{4}\end{array}$ & $\mathrm{mg} / 1$ & 0.46 & 1.0 & $\begin{array}{l}\text { Permanganom } \\
\text { etric }\end{array}$ \\
\hline & 2.6 Nitrate & $\mathrm{mg} / 1$ & Below 0.001 & 45 & $4500-\mathrm{NO}_{3}-\mathrm{B}$ \\
\hline & $2.7 \quad$ Nitrite & $\mathrm{mg} / 1$ & Below 0.001 & 0.005 & $4500-\mathrm{NO}_{2}-\mathrm{B}$ \\
\hline & 2.8 Ammonium & $\mathrm{mg} / 1$ & Below 0.04 & 0.15 & $4500-\mathrm{NH}_{3}-\mathrm{C}$ \\
\hline & 2.9 Sulfate & $\mathrm{mg} / 1$ & 8.21 & 200 & $4500-\mathrm{SO}_{4}^{2}-\mathrm{E}$ \\
\hline & 2.10 Chloride & $\mathrm{mg} / 1$ & 97.70 & 250 & $4500-\mathrm{Cl}-\mathrm{B}$ \\
\hline & 2.11 Floride & $\mathrm{mg} / 1$ & 0.16 & 1.0 & 4500-CF--B \\
\hline & 2.12 Cynide & $\mathrm{mg} / 1$ & Below 0.01 & 0.05 & $4500-\mathrm{CN}-\mathrm{B}$ \\
\hline & 2.13 Iron & $\mathrm{mg} / 1$ & Below 0.04 & 0.3 & $3500-\mathrm{Fe}-\mathrm{B}$ \\
\hline & 2.14 Manganese & $\mathrm{mg} / 1$ & Below 0.02 & 0.05 & 3500-Mn-B \\
\hline & 2.15 Free Chlorine & $\mathrm{mg} / 1$ & Below 0.02 & 0.1 & $4500-C 1_{2}$ \\
\hline & 2.16 Heavy Metal: & & & & \\
\hline & 2.16.1 Lead & $\mathrm{mg} / 1$ & Below 0.01 & 0.05 & $3500-\mathrm{Pb}-\mathrm{B}$ \\
\hline & 2.16.2 Copper & $\mathrm{mg} / 1$ & Below 0.03 & 0.5 & 3500-Cu-B \\
\hline & $\begin{array}{c}2.16 .3 \\
\text { Cadmium }\end{array}$ & $\mathrm{mg} / 1$ & Below 0.005 & 0.01 & $3500-c d-B$ \\
\hline & 2.16.4 Mercury & $\mathrm{mg} / 1$ & Below 0.001 & 0.001 & $3500-\mathrm{Hg}-\mathrm{B}$ \\
\hline \multirow[t]{6}{*}{3} & Bacteriological : & & & & \\
\hline & 3.1 TP (Fabric) & per $\mathrm{ml}$ & - & $1.0 \times 10^{2}$ & $9215 \mathrm{~B}$ \\
\hline & 3.2 TPC (market) & per ml & $4.0 \times 10^{4}$ & $10 \times 10^{5}$ & $9215 \mathrm{~B}$ \\
\hline & 3.3 Coliform & $\begin{array}{c}\text { per } 100 \\
\mathrm{ml}\end{array}$ & Nil & $<2$ & $9222 \mathrm{~B}$ \\
\hline & 3.4 Salmonella sp & $\begin{array}{c}\text { per } 100 \\
\mathrm{ml}\end{array}$ & Negative & Negative & $9260 \mathrm{D}$ \\
\hline & 3.5 Clostridium sp & per ml & Negative & Negative & $\left.{ }^{\star *}\right)$ \\
\hline
\end{tabular}

*) Standar Methode, 19th Edition 1995, APHA-AWWA-WEF

**)"The testing of water" SNI 01-3554-1994 


\section{LAMPIRAN :}

\section{UNIT PENGOLAHAN AIR SIAP MINUM KAPASITAS 20.000 LITER PER HARI}

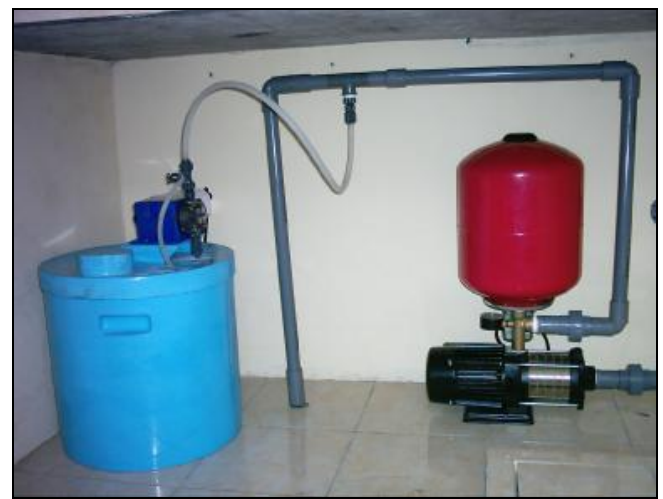

Pompa Air Umpan, Pompa Dosing, Tangki Kimia.

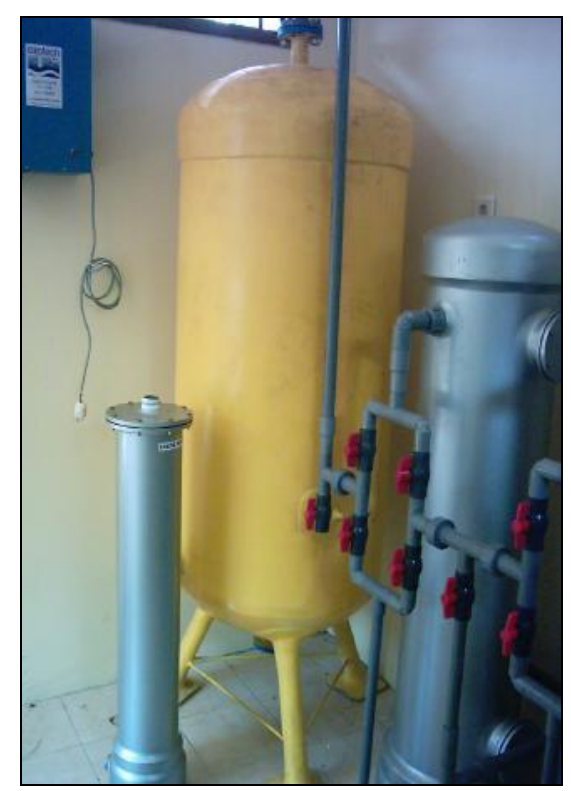

Static Mixer dan Tangki Reaktor

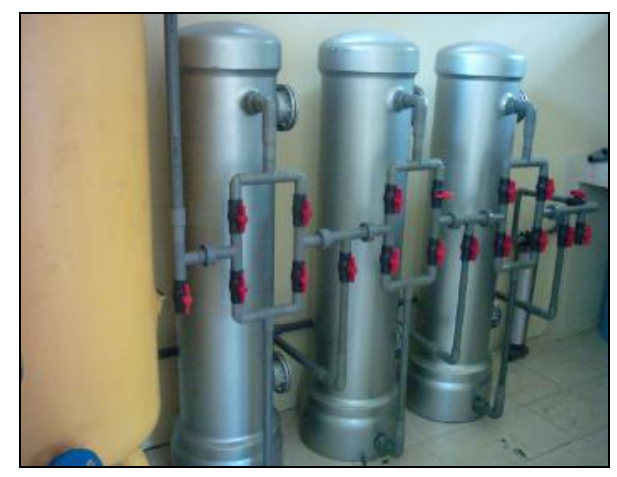

Saringan Pasir Cepat, Filter Mangan Zeolit dan Filter Carbon Aktif.

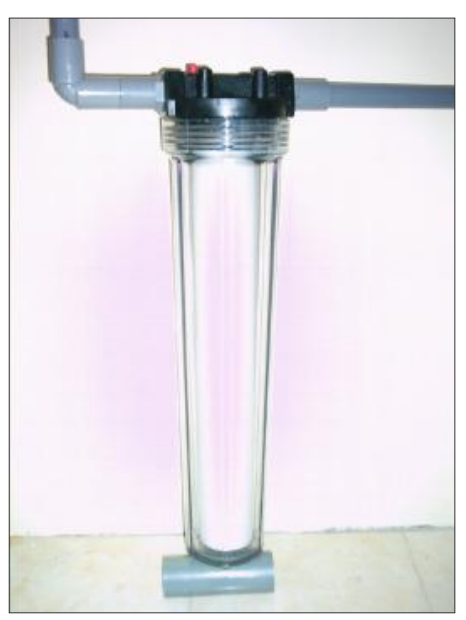

Filter Cartridge.

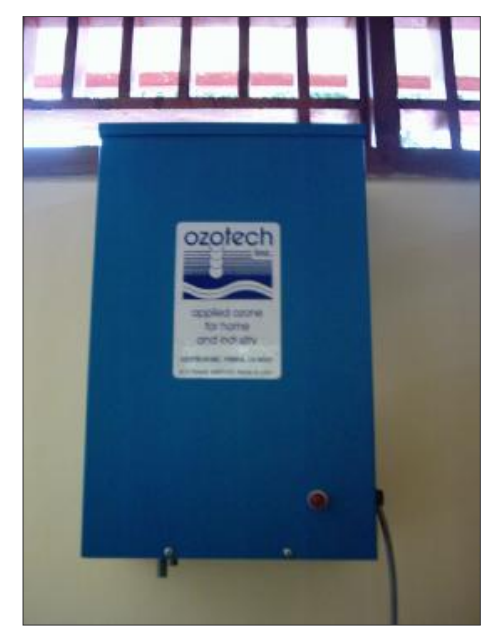

Ozon Generator.

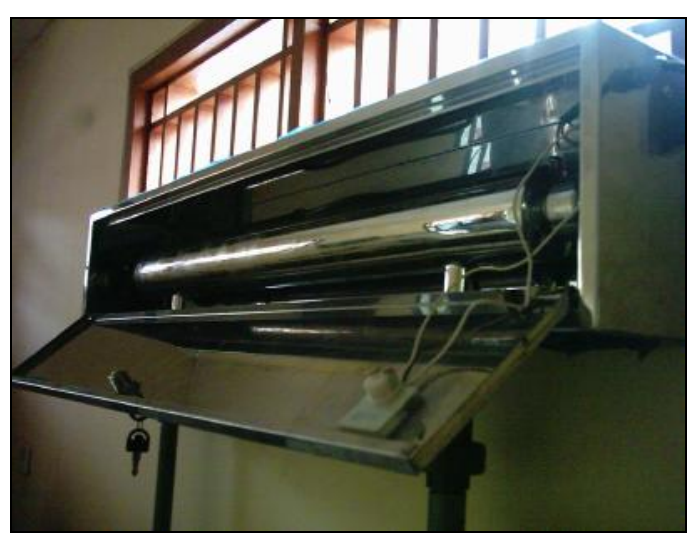

Sterilisator Ultra Violet (UV). 